\title{
THE CHEMISTRY OF NATURAL PRODUCTS
}

$\mathrm{I}^{\mathrm{N}}$ $\mathrm{N}$ the Great Hall of the University of Sydney on August 25 Sir Kenneth Street, Lieutenant-Governor of New South Wales, formally closed the ten-day Symposium, entitled "The Chemistry of Natural Products", which had been opened on August 15 by Sir John Eccles, president of the Australian Academy of Science, in the Wilson Hall of the University of Melbourne. The meeting had made history as the first outside Europe and North America to be sponsored by the International Union of Pure and Applied Chemistry. Some 150 chemists from 33 countries, together with more than 200 Australians, attended as registered members. From overseas, Prof. A. Stoll (Switzerland), past president of the International Union of Pure and Applied Chemistry, represented the present president, Prof. W. A. Noyes, jun. The United Kingdom delegates were led by two Nobel laureates, Sir Alexander Todd and Sir Robert Robinson. Prof. R. Kuhn, also a Nobel laureate, due to arrive from Heidelberg, was unfortunately absent through illness.

The Symposium has differed from those hitherto held in other countries in that it was not located only in one eity. It began in Melbourne in the State of Victoria, where it remained during August 15-18, then migrated about 300 miles to Canberra in the Australian Capital Territory, and finally shifted another 200 miles to Sydney; these movements all being made by air.

The Symposium was organized by the Australian Academy of Science, and the choice of subject was logical because the investigation of the constituents of Australian plants has formed the longest continuing organo-botanical-chemical research endeavour of scientists in Australia during the past century. In a sense its origin can be said to lie with Dr. John White, surgeon-general to the 'first settlement', who-soon after 1788--ran out of English peppermint oil, and discovered that an efficient substitute could be obtained by distillation of the leaves of the eucalyptus growing around Sydney Harbour. Prof. John Read (one-time professor of organic chemistry in the University of Sydney) devoted a whole chapter of his "Humour and Humanism in Chemistry" to this and subsequent periods under the title: "Chemistry Reaches the Australian Bush". Half a century ago the pioneering investigations of Smith and Baker (in what is now the Sydney Museum of Applied Arts and Sciences), followed later by those of Read himself, and Penfold (for many years director of the Museum) and others, have given Australia a significant place in essential oil and terpene research.

Alkaloids were first extracted from Australian sources in 1861. Shortage of certain drugs during the Second World War, and the problem of stock poisons occurring in plant foods, have caused a more intensive and systematic examination of Australian flora, and have led to the setting up of a phytochemical survey ; this has stimulated much research in university and government laboratories, and brought to light many novel colouring matters, glycosides, alkaloids, toxic or pharmacologically active compounds, etc., which were reported during the Symposium.
The scientific proceedings were divided into four sections, namely: (A) Aliphatic and Homocyclic Chemistry ; $(H)$ Heterocyclic Chemistry ; $(B)$ Biological Chemistry; and $(P)$ Physical Methods. Owing to the large number of papers submitted, the first three sections unfortunately (for the chemists interested) ran as concurrent sessions. Pillars in the construction of the programme were 14 lectures, attended by the whole assembly. At the opening ceremony, Prof. A. Stoll (Switzorland) spoke on "Impact of Studies of Natural Products on Chomical Industry". Three symposium lectures were delivered as follows: Section A, Prof. E. Sorm (Czechoslovakia), "Terpenic Compounds with MediumSized Rings"; Section $H$, Prof. R. B. Woodward (United States), "The Total Synthesis of Chlorophyll"; and Section $P$, Dr. H. W. Thompson (United Kingdom), "Physico-Chemical Methods of Studying Natural Products". Prof. Kuhn's eagerly awaited "Chemistry of the Gangliosides" had perforce to be omitted. Eight section lectures, also attended by all delegates, were: Section $A$, Prof. D. H. R. Barton (United Kingdom), "Some Aspects of Terpenoid and Steroid Chemistry", and Prof. N. A. Sørensen (Norway), "Structural Patterns of Poly. acetylenic Compounds isolated from the Plant Family Compositæ" ; Section $H$, Prof. H. Brockmann (West Germany), "Chemistry of the Actinomycins", and Prof. T. R. Govindachari (India), "Recent Investigations on Some Alkaloids from Indian Plants" ; Section B, Dr. J. W. Cornforth (United Kingdom), "The Biosynthesis of Polyisoprenoids", and Prof. E. Lederer (France), "Chemistry and Biochemistry of Biologically Active Bacterial Lipids"; Section P, Prof. C. Djerassi (United States), "Application of Optical Rotatory Dispersion Studies to Problems in Natural Products Chemistry", and Dr. A. McL. Mathieson (Australia), "The Direct Determination of the Molecular Structure of Natural Products". Dr. J. R. Price (Australia) gave a special lecture entitled "Australian Natural Product Re. search",

Sir Alexander Todd, as president of the Sym. posium, gave as his presidential address in the new Academy headquarters in Canberra a general review, coupled with a plea that biochemistry must bridge biology and organic chemistry, by studies of function and structure, if it is to make its most successful contribution to knowledge. He spoke on "Natural Product Chemistry-Retrospect and Prospect".

Sir Robert Robinson summed up the scientific achievements of the Symposium at its closing ceremony. He said : "It would be presumptuous for me, or anyone else for that matter, to pretend to be able to perform adequately the task which I must now attempt. For one thing, none of us has been able. as we might have wished, to be in three places at the same time. Furthermore, the printed abstracts are largely of the nature of appetizers, an invitation to the lunch, but with a masterly reticence with regard to the menu, to say nothing of the details of the cooking". . . "For me it has been throughout 
an entrancing and spectacular display of progress and promises of future advances". Sir Robert specifically referred to Dr. Thompson's lecture, saying that although Thompson himself was a pioneer of infra-red spectroscopy he "gave pride of place to X-ray crystallography, because this method gives full structural information-not only that, but also solves the stereochemical problems". Sir Robert proceeded to note the part taken by Djerassi's work on optical rotatory dispersion, by mass spectrometry and by nuclear magnetic resonance, as well as by infra-red and ultra-violet spectra, in the discussions and lectures of the Symposium. He warned, however, that the classical organic chemist is certainly not to be displaced by machines . . . there is no need to discuss whether an absorption band is due to $\mathrm{N}-\mathrm{H}$ or $\mathrm{O}-\mathrm{H}$ if the compound does not contain nitrogen, "even if we know the structure we still have to explore the surrounding chemical territory . . . would it be good for organic chemistry as a whole if the structure of indigo had been solved by looking at a few milligrams of it, and if Baeyer had not carried out any of his wonderful work which led to the determination of its formula? I think not !"

He went on : "We were greatly privileged to hear the lecture by Prof. R. B. Woodward, in which he described, I believe for the first time, the outstanding achievement of the total synthesis of chlorophyll. Prof. Woodward is not only a most brilliant synthetic organic chemist, but also an expositor, able to convey a sense of the drama of development to his audience. His lecture was thoroughly enjoyable, even thrilling as an experience. No doubt in places he admitted to a little good fortune, but he also made it clear it was expected. I was reminded of Benjamin Franklin's 'Luck is the bonus that accrues to industry'. Woodward and his team were surely industrious".

"This achievement of the synthesis of chlorophyll is a very good example of the kind of thing which one is often asked about ... What good is it ? Of course, the good that it is, is the new knowledge which is obtained . . . the new knowledge of the behaviour of chlorophyll, the nature of the molecule, how it is likely to behave in other circumstances. . . . That new knowledge may lead us we don't know where".

About Prof. Lederer's lecture Sir Robert said: "It was quite outstanding in interest and importance. I had no means for measuring decibels of applause or its duration, but it was elear my assessment was widely shared. Lederer described extensive studies on biologically active bacterial lipids. . . . He explained in full the problems which had been finally solved, and even more useful, he indicated the stages reached in the solution of others, including some which may have great significance for the therapy of tuberculosis in the future. Lederer's mastery and humorous style charmed us. His contribution will certainly be remembered".

He continued: "Another aspect which has been running through the Symposium is that of biogenesis and structural relations, and the use of isotopic tracers to test the various hypotheses advanced in this connexion. . . I I think the lecture by Dr. J. W. Cornforth was an extremely important event in the conference-one of the real highlights. The way in which Cornforth was able to describe the complete story for the synthesis of polyisoprenoids was quite remarkable. It was . . . a lecture of great value to all of us".
Sir Robert then referred in terms of praise to all the other lectures mentioned above, to the "infectious enthusiasm" of Erdtman, the "brilliance" of Barton, Sorm and Brockmann, the many valuable and novel facts presented by Sørensen, Govindachari and Mathieson, impossible to summarize in the detail they deserve. Concerning Prof. Stoll's review of the impacts which natural product research has on industry, Sir Robert said : "These reverberations are important . . . Stoll's work is as academic as anyone else's ... he has made extraordinarily valuable and neat contributions to the chemistry, for example, of the digitalis and ergot series". These have not been without profit in all senses of the word. Sir Robert paid a tribute to the survey of past and present Australian work by Dr. Price in his special lecture, and to the results presented by Price and collaborators in papers to Sections $H$ and $P$. These, he said, showed how many opportunities exist in Australia for natural product research, and how beneficial has been the guidance of Dr. Price and his associates in the laboratories of the Commonwealth Scientific and Industrial Research Organization.

Sir Robert concluded: "Possibly the outstanding scientific value of the Symposium has been the opportunity it has afforded for the meeting of colleagues from all over the world for discussions . . . not only in the lecture theatres, but also in other places where we meet and talk together. . . . It has been the most outstandingly successful symposium I personally have ever taken any part in. I have never experienced a symposium in which so many papers of the greatest possible interest have been delivered . . . and I must say that $I$ think it is due to the enthusiastic coming together of organic and physical chemists in the past twenty years, from which union we have gained advantages of powerful procedures . . . of chromatography, ordinary and vapour phase, of micro methods of analysis and of manipulation, of the many physical ways of examining products, of the availability of isotopes, and the techniques for handling them, and from which we can still see further new methods developing on the horizon ... all this has made the Symposium a most significant occasion. We hope to repeat it in Czechoslovakia in 1962".

Sir Robert then spoke with appreciation of Sir Alexander Todd's services as president of the Symposium-this was received with great applauseand the meeting was closed by Sir Kenneth Street.

Officially the planners received strong support in high places. His Excellency the Governor-General of Australia, Viscount Dunrossil, was patron-in-chief, and Their Excellencies the Governors of New South Wales and of Victoria were patrons.

Official receptions were given by the Premiers of Victoria and New South Wales in Melbourne and Sydney respectively, and by the Prime Minister in Canberra. Immediately prior to the opening, Sir Alexander Todd received the honorary degree of doctor of laws from the University of Melbourne, and on August 24 the University of Sydney conferred on Sir Robert Robinson (first professor of organic chemistry in Sydney) its D.Sc. (honoris causa).

A full programme of social events and excursions for members and their ladies was also carried through. Outstanding were the Government receptions, the banquet in Canberra, a "wine and cheese tasting' in Sydney by courtesy of the Australian Wine Producers' Association of New South Wales, and a fashion parade in Melbourne of Australian 
woollens, arranged by the Australian Wool Board. The last two, together with the many scenic tours possible from the three centres, proved of great interest to visitors who had not previously seen the Australian way and place of life. Post-Symposium tours to north and south Queensland and to New Guinea are now in progress-the last-named being for men only and at the invitation of the Commonwealth Government and the New Guinea Administration.

The lectures mentioned above will be published through the Publications Committee of the International Union of Pure and Applied Chemistry by Butterworth's Scientific Publications, London.

R. J. W. LE Fìvre

\section{WARREN SPRING LABORATORY}

TN planning the Warren Spring Laboratory at Stevenage, the Council for Scientific and Industrial Research decided that it should be a versatile station free to carry out research which cannot be fitted into the programme of another research body, especially work involving pilot-scale investigations of any subject of national importance.

As a result, the Laboratory's research programme includes a number of important investigations in several different fields*.

In chemical engineering, for example, the work is concerned mainly with providing the chemical plant designer with basic information. Considerably moro knowledge is required to achieve greater precision in design work. The basic programme is confined to the study of mass transfer in gas-liquid systems, and these investigations will provide data for the precise design of large-scale equipment without the need for costly pilot-plant studies. For example, the investigation should enable more accurate prediction of the performance of gas-liquid contacting equipment to be made and thus facilitate the design of equipment such as distillation columns and gas absorption towers.

Much of the work of the Mineral Processing Division is undertaken for mining companies and other organizations, on repayment. Three main subjects of basic research are being studied: (a) grinding in the presence of additives such as surfaceactive agents ; $(b)$ the composition of surface minerals and the kinetics of bubble attachment to mineral surfaces ; $(c)$ the behaviour of mineral particles in a high-tension field and the modifications of this behaviour by various surface treatments. There have been indications during the year that automation may become important in mineral processing plants and an experimental programme is being considered.

In the Process Development Department, work has continued on the Fischer-Tropsch synthesis,

* Report of the Warren Spring Laboratory, 1959. Published for the Department of Scientific and Industrial Research. (London: H.M. Stationery Office, 1960.) 3s. net. which provides a method of obtaining liquid and gaseous fuels from carbon monoxide and hydrogen, which are produced by the complete gasification of low-grade high-ash coal. Basic research on catalysis has included work on the catalytic and other physicochemical aspects of fuel cell operation.

A small human sciences research team is being formed at the Laboratory, and tho Human Sciences Research Sub-committee, under the chairmanship of Mr. H. Briggs, labour adviser to Unilever, Ltd., is now considering the programmes of research in this increasingly important field.

Current research into air pollution concerns both methods of abatement and assessment of atmospherie pollution throughout Britain, with relation to the effects of clean air legislation. Estimates madc during the year have shown that, in general, smoke from the burning of industrial coal has ceased to be a serious problem although in some instances it creates a local nuisance. The Laboratory has cooperated with the Port of London Authority and owners of tugs in demonstrating methods of reducing smoke emission from ships in coastal waters.

Smoke from Diesel exhausts provides another research problem. While a well-maintained and correctly operated Diesel vehicle need never produce black smoke, the fact remains that large numbers of lorries frequently do. Methods of removing smoke from exhaust gases are being studied. A 10-ton Diesel lorry fitted for road tests with various proprietary devices is being used for this purpose.

The Laboratory has continued to collaborate with local authorities on the measurement of pollution, and this is providing "a wealth of background information against which future improvements can be assessed".

Methods of measuring low concentrations of oxides: of nitrogen (known to be emitted by practically all fuel-burning appliances) are being examined. These emissions may be significant factors in air pollution.

\section{U.K. ATOMIC ENERGY AUTHORITY}

$\mathrm{T}$ HE sixth annual report of the Atomic Energy Authority, the first to appear over Sir Roger Makin's signature and also the first to be submitted to the Minister for Science, covers the period April 1, 1959-March 31, 1960*. During that year, those major projects undertaken primarily to support the

* United Kingdom Atomic Energy Authority. Sixth Annual Report for the period 1st April, $1959-31$ st March, 1960 . Pp. vi $+72+4$ plates. (London: H.M. Stationery Office, 1960.) 5s. net. defence programme were completod, and all main plants constructed for that purpose were operating successfully. New capital projects approved during the year were on a relatively small scale. The Authority continued to devote a major effort in support of the civil power programme of the Central Electricity Generating Board and the South of Scotland Electricity Board. The report includes as an appendix the observations of the Ministor for Science, in con- 